\title{
Students Assessment of Teacher's Ability and Knowledge, Attitude \& Economic Skill of Students Based on the Indonesian Economy
}

\author{
Nanis Hairunisya ${ }^{1}$, Imam Sujono $^{2}$, Hari Subiyantoro ${ }^{3}$, Sulastri Rini Rindrayani ${ }^{4}$ \\ \{nanis.hairunisya@stkippgritulungagung.ac.id\}
}

STKIP PGRI Tulungagung, Indonesia ${ }^{1,2,3,4}$

\begin{abstract}
Student's knowledge about real economic condition is apprehensive. They do not understand about the importance of understanding economic values based on the ideology of the nation. Students do not really understand the economic value, which points to the mandate of the Constitution and Nation's ideology. The objective of this research was to analyze student's assessment of teacher's ability and knowledge, attitude and skill of students in the Economy of Indonesian-based Economy in order to development of economic books. The method of this research was descriptive qualitative method. This research was conducted in six districts in East Java Province. Data collection methods used questionnaires and tests.. The results showed that most students assessed their economic teachers as having good mastery of the material, but the ability to manage and carry out economic learning was low. The test results of students' knowledge of economic problems are of concern. There is a gap between the learning experience that students receive and the subject matter of students' knowledge tests about economic problems. This provides information that basically the implementation of economic education for high school students in this country is still not able to provide understanding and mastery of knowledge about problems and economics as should be idealized. This finding will influence the development of economic books and inform future interventions in economic education curriculum design..
\end{abstract}

Keywords: Student assessment analysis, Knowledge, attitudes and economic skills of students in economic, the development of economic books.

\section{Introduction}

Economic education can be interpreted as a process of awareness of students about making decisions based on the economic principles, and making students have economic literacy. It means making students have ability and individual awareness about what, think and how to find smart consumers, wise producers, savers and investors, productive workers and responsible citizens (CEE: www.councilforeconed.org).[1]. Based on the definition above, it is feasible to think about the urgency of economic education as a vehicle to build quality human resources that have a significant contribution to the achievement of national progress. 
Awareness of the importance of developing and implementing economic education that refers to the philosophy of Pancasila 1 and economic values based on the 1945 Constitution has long emerged and developed among economic education experts and observers. Nevertheless, the intended interest has not been realized until the introduction and application of the 2013 Curriculum. The contents of core competencies and basic competencies that exist in the curriculum, which are used as references in developing economic education materials, do not yet contain the basic essence of the economic values, in accordance with the nation's philosophy and mandate of the 1945 Constitution. Citing Witjaksono'sthinking (2013)[2] about the need for redefinition, reorientation, and redesign of economic learning that refers to amendments 1945Constitution, Article 33.

At the micro level, problems that are close to students can be used as development material, such as household economic management, management of small businesses around students, the impact of the proliferation of "Indomaret" and "Alfamart" for small traders, and so forth. The development of economic learning with actual discussions requires an increase in teachers' skills. It can be done through training and providing learning resources that can be used by teachers to study independently or in groups.

Several factors influence the quality of economic learning. To facilitate identification, it can be grouped into factors that are directly related and which are not directly related to the implementation of economic learning.

One of the factors that directly affect the quality of economic learning is the condition of students. These various things related to students are logical and empirical (proven through research results). These things are factors that can affect the quality of economic learning.

The results of Adjani and Adam (2013: 8) [3] researchh revealed that students' learning experiences and motivations had a positive influence on their learning achievement, while the family environment and teaching quality did not significantly influence learning achievement.Adjani and Adam also revealed that if the student is interested in a particular subject or course, he usually tends to listen and understand the material given and this brings a positive impact on learning achievement.Iskandarsyah and Imam Ghozali (2012: 10) [4] in his research concluded that the factors that can affect student learning achievement include lecturer's teaching style, assistance to students, structure of lectures, and learning facilities. Meanwhile Shan Li and Juan Zheng [5] found that the personality characteristics of each student were not very related to learning effectiveness, team personality characteristics related to learning effectiveness

From the results of the preliminary study, the mastery of the basics of economic theory is good, but there are still some misconceptions over their understanding. Their knowledge of the surrounding economic phenomena and general macroeconomic problems is inadequate. Meanwhile, their understanding of the economic value of Indonesia is very deficient.Nevertheless, they expressed pleasure in learning economics compared to other subjects in the social science interest group.Based on the facts above, we need an in-depth study of student perceptions, especially on Student Assessment of Teacher Ability and Knowledge, Attitudes and Skills of Students in Indonesian-based Economy of Economics in order to develop economic learning material.

\footnotetext{
${ }^{1}$ Pancasila is Nation's ideology of Indonesia
} 


\section{Method}

The subjects in this study were economic students and teachers in six cities/districts, which were selected as research locations. Each of the six districts/cities would be selected ten economic teachers, so that the overall subjects in this study were 60 teachers. The selection of research subjects wasconducted purposively based on teaching experience. In addition to the teacher, the subjects in this study were students who would measure their mastery of concepts and economic problems, especially those related to the Indonesian-based economy. Students who were used as research subjects were five people who were taught by teachers who had been determined as research subjects. Thus, the number of students used as research subjects was 300 people

The methods used to collect data are the questionnaire method and test. The questionnaire method in this study was used to collect data about polls and student assessment of teacher's abilities. Polling Variables and Student Assessments of Teacher Abilities are divided into subvariables Teacher mastery of subject matter, and sub-variables Ability to manage and implement learning. Test material includes: (1) knowledge of economic and economics problems, (2) attitudes to economic and economic problems, and (3) skills in economic behavior.

The development of tests to measure the level of knowledge of economic and economics problems is carried out by referring to the basic economic ability test (economic literacy), which is enriched with advanced knowledge about economic problems around students and basic economic theories covering microeconomics, macroeconomics, monetary economics, international economy, and the Indonesian-based Economy. The provisions for the level of difficult a test item having a high is between $0,00-0,30$, mediumis between $0,31-0,70$ and low is between $0,71-1$.

The results of different power measurements were carried out by determining the difference in the ratio of the number of test participants who answered correctly and the total number of participants in the proportion of students with high ability and the total number of test participants in the group of low-ability students. The formulation is as follows:

$$
\mathrm{R}_{\mathrm{t}}-\mathrm{R}_{\mathrm{r}}
$$

Where, $R_{t}$ is the ratio between the number of test participants who answered correctly and the total number of participants in the proportion test in the upper class group, while $\mathrm{Rr}$ is the ratio between the number of test participants who answered correctly and the total number of test participants in the lower class group. The measurement results prove that in general, the test items do not have good differential power; this is due to the high difficulty level of the test. It causesonly few students who can answer the questions correctlyboth in the upper class group and the lower class group. The test was developed with material basic concepts that became the standard of economic knowledge at high school level. Some of them were not covered in the 2013 curriculum.Data analysis was only carried out descriptively in accordance with the characteristics of the collected data and the purpose of the study, that is to obtain contextual understanding of the conditions of teacher professional competence and its relevance to student mastery of economic concepts and problems, especially those related to the Indonesian-based economy. 


\section{Results And Discussion}

\subsection{Results of Student Assessment of Teacher Ability and Implementation of Economic Learning}

Distribution of the number of students according to opinion and assessment of teacher mastery of subject matter is tabulated as follows:

Table 1: Distribution of frequency of opinions and assessment of students about teacher mastery of economic subject matter

\begin{tabular}{rrlrcr}
\hline No & Interval & Criteria & Frequency & \% Frequency & \% Cumulative \\
\hline 1 & $30-35$ & Very good & - & - & 22 \\
2 & $24-29$ & Good & 66 & 60 & 22 \\
3 & $18-23$ & Sufficient & 180 & 13 & 82 \\
4 & $12-17$ & Less & 39 & 5 & 100 \\
5 & $7-11$ & Very Less & 15 & 100 & \\
& & Total & 300 & & \\
\hline
\end{tabular}

It was proven that most students argued and judged that their economics teacher master the subject matter with a fairly good statement, even more than $20 \%$ stated well. Nevertheless, there are some students said less and very less. Judging from the indications developed, most of students judge sufficient and less related to the teacher's knowledge of up to date economic phenomena, and the ability of teachers to provide illustrations in learning.

This should be a serious concern for teachers, that economic learning is different from learning other social sciences. Understanding of up to date information and giving illustrations is very important because of the high dynamics of economic knowledge and the proximity of economic problems to the students'daily life.5 indicators are developed to find out opinions and assessments of students about the ability of teachers to manage and implement economic learning. The five indicators are: (1) the ability of teachers to carry out good and enjoyable learning, (2) ability to show sympathy and empathy, (3) mastery of emotions and patience in guiding students, (4) ability to manage classes well, and (5) authoritative, disciplined, and democratic.The five indicators were developed into 11 questions in the questionnaire, which answers of each item scored with a value scale of 1 to 5.Thus, the maximum expectation score of student answers will be 55 and the minimum expectation score is 11 .The distribution of the number of students is categorized according to their opinion and assessment of the ability of the teacher to manage and carry out economic learning. This can be tabulated as follows:

Table 2: Frequency Distribution of Opinions and Student Assessments on Teacher's Ability to Manage Economic Learning

\begin{tabular}{rrlccc}
\hline No & Interval & Criteria & Frequency & \% Frequency & \% Cumulative \\
\hline 1 & $43-50$ & Very good & 42 & 14 & 14 \\
2 & $35-42$ & Good & 153 & 51 & 65 \\
3 & $27-34$ & Sufficient & 78 & 26 & 91 \\
4 & $19-26$ & Worse & 24 & 8 & 99
\end{tabular}




\begin{tabular}{cccccc}
\hline No & Interval & Criteria & Frequency & $\%$ Frequency & \% Cumulative \\
\hline 5 & $10-18$ & Worst & 3 & 1 & 100 \\
& & Total & 300 & 100 & \\
\hline
\end{tabular}

In contrast to the opinions and judgments of students about the mastery of teachers on economic subject matter, students' opinions and judgments about the ability of teachers to manage and carry out economic learning tend to be less favorable. When it is traced from the developed indicators, the less score of assessment from student is related to the indicator of the teacher's ability to carry out learning well and pleasantly, the ability to show an attitude of sympathy and empathy, and authoritative, disciplined, and democratic. The first indicator relates to teacher's weaknesses to be able to presentvaried and enjoyable learning methods strategies. This is in line with the results of observations made. Most teachers develop discussion methods that are less preceded by adequate expository material. In addition, not all students are active in group discussion activities. Weakness in showing sympathy and empathy as well as authority, discipline and democracy is more related to the teacher's personal competence. Teachers are less touched by teacher development programs, which are developed by the educational bureaucracy. For this reason, it is necessary to develop programs to improveteacher personality competency in the future.

\subsection{Results of Analysis of Attitude Knowledge and Student Skills in Economics}

The frequency distribution resulting from the assessment of students' knowledge of problems and economics from the 100 students used as respondents in the study can be tabulated as follows:

Table 3: Frequency Distribution of Student Knowledge Test Results on Problems and Economics

\begin{tabular}{rrlrcc}
\hline No & Interval & Criteria & Frequency & $\%$ Frequency & $\%$ Cumulative \\
\hline 1 & $80-100$ & Very high & - & - & - \\
2 & $60-79$ & High & 21 & 7 & 7 \\
3 & $40-59$ & Sufficient & 141 & 47 & 54 \\
4 & $20-39$ & Low & 99 & 33 & 87 \\
5 & $0-19$ & Very Low & 39 & 13 & 100 \\
& & Total & 300 & 100 & \\
\hline
\end{tabular}

The test results of students' knowledge of economics and economics problems are of concern. This is understandable because the test instrument used to measure is ideal, in accordance with the expected material that should be translated and mastered by high school students. While the curriculum and economic learning absorbed by students do not cover all the basic material used as the basis for compiling test instruments. The gap between learning experiences received and undertaken by students, and the subject matter of tests of students' knowledge of economics and economics problems, can be confirmed as the cause of the low achievement of students in the tests given in product evaluation in this study.Nevertheless, this provides information that basically the implementation of economic education for high school students in this country is still unable to provide understanding and mastery of knowledge of economics and economics problems as should be idealized. 
To measure the domain of attitudes towards students' problems and economics, there are 2 main material that are used as the basis for developing test instruments. The first is attitudes towards economic problems with sub-material attitudes towards poverty, unemployment, economic inequality, economic environment, consumptive lifestyle, and global economic competition. The second is attitudes toward economics with the sub-subject matter of attitudes towards rationality and altruism, economic morality, economic affairs, and the benefits of economics. To measure the attitude in question, 30 objective items were developed. The frequency distribution of the results of evaluating students' attitudes to economics and economics problems from the 100 students used as respondents in the study can be tabulated as follows

Table 4: Frequency Distribution of Results of Student Attitude Tests on Problems and Economics

\begin{tabular}{rrlrcc}
\hline No & Interval & Criteria & Frequency & \% Frequency & \% Cumulative \\
\hline 1 & $80-100$ & Very high & 6 & 2 & 2 \\
2 & $60-79$ & high & 24 & 8 & 10 \\
3 & $40-59$ & sufficient & 126 & 42 & 52 \\
4 & $20-39$ & Low & 57 & 19 & 71 \\
5 & $0-19$ & Very low & 87 & 29 & 100 \\
& & Total & 300 & 100 & \\
\hline
\end{tabular}

The distribution of attitude test results on economics knowledge and economics problems is different from the results of previous tests.Nevertheless, in generalthe test result is the same in terms of achievement, that is equally low, even on attitude test results on problems and economics, almost $30 \%$ of students get very lowgrades.Problems related to attainment of attitudinal learning outcomes in economic education in high school are caused by the lack of attention of teachers in instilling attitudes towards economics knowledge and problems to students.From the results of the research, on the developed indicators, students' weaknesses in addressing economic problems are related to matters relating to poverty, economic gap, consumptive lifestyle, and global economic competition.It must be realized that the topics related to the problem are indeed not revealed in the curriculum and material of economic learning in high school.

To measure the domain of skills in students' economic behavior, there are 2 main material that are used as the basis for developing the test instruments. The first is the skills to manage personal money with sub-skills materials: managing economic needs and desires, making economic choices and decisions, calculating opportunity costs, consuming and saving.the second is productive behavior skills with the main sub-material in the form of skills for: developing business ideas, arranging business management plans, and working on business projects in groups.An objective test was developedto measure the skills. There are 10 items to measure the first skill, while for the second skill, students were givenindividual and group assignments, and the assessment was given individually on the results of the assignments collected by students.Assessment was carried out by combining test results and the value of the assignments they are working on. Results of frequency distribution from the assessment of students' skills in economic behavior, which is consist of 90 students who were selected as research respondents, can be tabulated as follows 
Table 5: Frequency Distribution of Results of Skills Tests in Students' Economic Behavior

\begin{tabular}{|c|c|c|c|c|c|}
\hline No & Interval & Criteria & Frequency & $\begin{array}{l}\% \text { Frequen- } \\
\text { cy }\end{array}$ & $\%$ Cumulative \\
\hline 1 & $80-100$ & Very high & - & - & - \\
\hline 2 & $60-79$ & High & 12 & 4 & 4 \\
\hline 3 & $40-59$ & Sufficient & 87 & 29 & 33 \\
\hline 4 & $20-39$ & Low & 147 & 49 & 72 \\
\hline \multirow[t]{2}{*}{5} & $0-19$ & Very low & 54 & 18 & 100 \\
\hline & & Total & 300 & 100 & \\
\hline
\end{tabular}

Students' skills in economic behavior in general are to be low, lower than the domain of knowledge and attitudes. The reason is predictable, that in economic learning, they rarely obtain learning experiences that hone skills in economic behavior. When tracing the submaterial used as the basis for its development, it is proven that weaknesses exist in indicators managing economic needs and desires, making choices and economic decisions, and consuming and saving.Moreover, the second sub-subject matter is related to productive behavior skills. This weakness is very evident from the number of students who are not able to complete the task independently in arranging business ideas and preparing a business management plan. While for the task of working on business projects in groups, only 12 of 60 groups were able to complete the task and submit the results of the report.

\section{Conclusion}

The results of this study indicate that most students assess sufficient and less related to the indication of teacher knowledge of up-to-date economic phenomena and the ability of teachers to provide illustrations in learning.This should be a serious concern for teachers, that economic learning is different from learning other social sciences. Understanding of up to date things and giving illustrations is very important because of the high dynamics of economic knowledge and the proximity of economic problems to students' daily lives. The results of this study are in line with the theory put forward by Schug, Mark C., \&Wood, William C. (Eds.). (2011)[6]. They illustrate the difficulties faced by a teacher who does not always enrich knowledge to face the challenges of the development of knowledge.The same thing was found in the research of Sulisworo (2017)[7]. who found conceptually that teachers as professionals must meet various competency requirements.

This study also found that teacher management in economic learning tended to be less favorable. This is related to the indicator of the teacher's ability to carry out good and enjoyable learning, the ability to display an attitude of sympathy and empathy, and authority, discipline, and democracy. this relates to the weakness of the teacher to be able to display strategies and learning methods that are varied and enjoyable.

This is in line with the results of Alimin's research (2015)[8]. He found that the competence of personalityteacher owned byTarakan Middle School teachers greatly influenced student learning. This study supports national education policies, formulations that have made bythe government about four types of teacher competencies, which are stated in the Explanation of 
Government Regulation No. 19 of 2005 concerning National Education Standards.[9] stery of knowledge of economics and economic problems as should be idealized.

The test results of students' knowledge of economics and economic problems are of concern. This is understandable because the test instruments used to measure are based on the subject matter of ideal expectations that should be understood and mastered by high school students. While the curriculum and economic learning absorbed by students does not cover all the basic material used as the basis for compiling test instruments. The gap between learning experiences received and experienced by students and the tests subject matter of students' knowledge of economics and economic problems, can be ascertained as the cause of the low achievement of students in the tests given to product evaluation in this study.Nevertheless, this provides information that basically the implementation of economic education for high school students in this country is still unable to provide understanding and mastery of knowledge of economics and economic problems as should be idealized.

It must be realized that the topics related to the problem are indeed not revealed in the curriculum and material of economic learning in high school. Weakness also appears in students' attitudes towards the economy related to rationality and altruism, economic morality, and economic affairs.It can also be assumed that the cause lies in the weakness of the teacher's understanding of the concepts in question, so that these concepts are less discussed in economic learning in high school. This is in line with research.The results of this study are in line with the findings of Mubarak et al (2017)[10]. He states that students who have economic knowledge will apply that knowledge in relevant life concepts. It was found that students who have high economic knowledge also have a high interest in saving. This can be interpreted that knowledge of high economics will play a role in taking attitudes in student economic behavior.

In line with the findings above, it has long emerged that awareness of the importance of the development and implementation of economic education refers to the philosophy of Pancasila and economic values based on the 1945 Constitution [11] and developed among economic education experts and observers.Even so, until the introduction and application of the 2013 curriculum, the intended interest has not been realized.The core contents and basic competencies that exist in the curriculum, which are used as a reference for developing economic education materials do not yet contain the essence of the basic economic values, in accordance with the nation's philosophy and mandate of the 1945 Constitution.Quoting from Witjaksono's(2013)[12] thinking that it is necessary to redefine, reorient, and redesign economic learning, which refers to amendments to Article 33 of the 1945 Constitution.

To realize Pancasila economic democracy, the design of economic learning starts from subject matter, implementation of learning, strategies and learning media, until the impact on the practice of economic life of students must be nuanced and full of precepts from the Pancasila (Witjaksono, 2013).Based on these thoughts, it is worth thinking about revitalizing economic education in Indonesia starting from improving the economic education curriculum, followed by improvements to textbooks and fundamental changes to the practice of economic learning in schools, especially secondary education.

The development of economic learning material carried out by teachers should also be enriched with various economic policies, which is equipped with the latest data to illustrate the implications (Wahyono, 2010).[13]. Development of economic learning should also include discussion of actual economic problems at the macro and micro level. 


\section{References}

[1] Council for Economic Education Teaching Opportunity. Economic or Economics Education. www.councilforeconed.org. Diunduh 15 April 2015.

[2] Witjaksono, Mit. 2013. Redefinisi, Reorientasi, dan Redesain Pembelajaran Ekonomi Mengacu Pada Amandemen Pasal 33 UUD 1945. Jurnal Pendidikan Ekonomi Vol. 6 No. 1, 2013. Jurusan Ekonomi Pembangunan, Fakultas Ekonomi, Universitas Negeri Malang

[3] Adjani,Sagita dan Helmi Adam. 2013. Faktor-Faktor yang Mempengaruhi Prestasi Belajar Mahasiswa pada Mata Kuliah Pengantar Akuntansi. Jurnal Ilmiah Mahasiswa FEB Universitas Brawijaya. Vol. 1 No.1.

[4] Iskandaryah, Doddy dan Imam Ghozali. 2012. Analisis Faktor yang Memengaruhi Prestasi Mahasiswa dalam Mempelajari Mata Kuliah Akuntansi Keuangan Menengah, Studi Empiris pada Mahasiswa Jurusan Akuntansi Reguler di Fakultas Ekonomika dan Bisnis Universitas Diponegoro tahun angkatan 2009 dan 2010). Diponegoro Journal of Accounting. Vol. 1 No. 2 : Hal. 1-13.

[5] Shan Li and Juan Zheng, 2018. A latent profile analysis of students' motivation of engaging in one-to-one computing environment for English learning, EAI Endorsed Transactions on e-Learning, (http://creativecommons.org/licenses/by/3.0/)

[6]Schug Mark C., Wood William C. (Editor), 2011. Teaching Economics in Troubled Times Theory and Practice for Secondary Social Studies. New York: Routledge

[7] Sulisworo, D. (2016). The Contribution of the Education System Quality to Improve the Nation's Competitiveness of Indonesia. Journal of Education and Learning (EduLearn), 10(2), 127-138.

[8] Alimin, Analisis Kompetensi Kepribadian Guru Pendidikan Agama Islam SMP di Tarakan, Jurnal Kebijakan dan Pengembangan Pendidikan Volume 3, Nomor 1, Januari 2015; 61-65, ISSN: $2337-$ 7623; EISSN: 2337-7615

[9] Government Regulation No. 19 of 2005 concerning National Education Standards

[10] Mubarak, Zakki , Wahjoedi , Mardon, Pengaruh Tingkat Pengetahuan Ilmu Ekonomi Dan Pemanfaatan Bank Mini Sekolah Terhadap Minat Menabung Siswa Kelas Xi Ips Sma Negeri 2 Malang, Jurnal Pendidikan Ekonomi, Vol.10, No.1, 2017 DOI: https://dx.doi.org/10.17977/UM014v10i12017p001

[11] Pancasila and the 1945 Constitution

[12] Witjaksono, Mit. 2013. Redefinisi, Reorientasi, dan Redesain Pembelajaran Ekonomi Mengacu Pada Amandemen Pasal 33 UUD 1945. Jurnal Pendidikan Ekonomi Vol. 6 No. 1, 2013. Jurusan Ekonomi Pembangunan, Fakultas Ekonomi, Universitas Negeri Malang

[13] Wahyono, Hari. 2010. "Merancang Peningkatan Profesionalitas Guru Ekonomi, Harapan Ideal dan Fakta Menyedihkan." Makalah disajikan dalam Seminar Nasional Pendidikan Ekonomi. Jurusan Ekonomi Pembangunan, Fakultas Ekonomi, Universitas Negeri Malang, 6 November 2010. 